\title{
The vaginal microflora changes in various stages of the estrous cycle of healthy female dogs and the ones with genital tract infections
}

\author{
Edyta Golińska, Natalia Sowińska²,3, Anna Tomusiak-Plebanek ${ }^{1}$, Marlena Szydło ${ }^{4}$, Natalia Witka ${ }^{5}$, \\ Joanna Lenarczyk $k^{6}$ and Magdalena Strus ${ }^{1 *}$
}

\begin{abstract}
Background: Inflammatory diseases of reproductive tract in bitches are a common problem in veterinary practice. The inflammation can lead to serious health problems. Research to determine the correlation between the health status of females, phase of the cycle, age and bacterial flora of the genital tract has been ongoing for years, but the results obtained by individual authors are often contradictory.

Results: A total of 39 dogs were included in this study. Ten were qualified to the 1 st group with genital tract infections ( 8 in anestrus and 2 in proestrus) and 29 to the 2nd group without such infections (16 in anestrus, 9 in proestrus and 4 in diestrus). The most common bacterial isolates obtained from the vaginal tract of all dogs were Escherichia coli, Staphylococcus pseudintermedius and Streptococcus canis. The prevalence of Gram-negative rods (other than E. coli) was significantly higher in the group with genital tract infections versus healthy dogs. There was no presence of Chlamydiaceae, Chlamydia abortus and lactic acid-producing bacteria in tested swabs.

Conclusions: Our study identified the most common bacteria in the genital tract of bitches. The total number of bacteria was almost the same in the healthy and infected dogs, as well as between the cycle stages. In our opinion, bacterial culturing of vaginal swab specimens from bitches without signs of genital disease is of little value. Furthermore, it should always be preceded by clinical examination and cytological examination of the vaginal epithelium.
\end{abstract}

Keywords: Genital tract, Microflora, Inflammation, Probiotics, Bitch

\section{Background}

Recurrent genito-urinary tract infections in bitches are a common problem in veterinary practice [1]. Vaginitis, both juvenile and adult-onset, infertility, abortion, foetus resorptions and mortality as well as cystic endometrial hyperplasia are among the most common disorders that might have a bacterial base [2-4]. As in the case of epithelium of other tissues which are in contact with

\footnotetext{
* Correspondence: magdalena.strus@uj.edu.pl

'Jagiellonian University Medical College, Czysta 18, 31-121 Cracow, Poland Full list of author information is available at the end of the article
}

external environment, like nasal cavity, oral cavity and alimentary tract, also vaginal epithelium and mucosa are colonized by physiological microflora [5]. Presence of bacteria, free or inside the epithelial cells, is frequently reported in vaginal smears of healthy dogs $[6,7]$. Depending on the cycle stage from $50 \%$ do $100 \%$ of clinically healthy dogs are characterized by a vaginal bacterial population, usually mixed, consisting of both aerobic and anaerobic microorganisms [8-10], often opportunistic pathogens. It has been shown that normal vaginal microbiota appears to protect genito-urinary tract

C C The Author(s). 2020 Open Access This article is licensed under a Creative Commons Attribution 4.0 International License, which permits use, sharing, adaptation, distribution and reproduction in any medium or format, as long as you give appropriate credit to the original author(s) and the source, provide a link to the Creative Commons licence, and indicate if changes were made. The images or other third party material in this article are included in the article's Creative Commons licence, unless indicated otherwise in a credit line to the material. If material is not included in the article's Creative Commons licence and your intended use is not permitted by statutory regulation or exceeds the permitted use, you will need to obtain permission directly from the copyright holder. To view a copy of this licence, visit http://creativecommons.org/licenses/by/4.0/ The Creative Commons Public Domain Dedication waiver (http://creativecommons.org/publicdomain/zero/1.0/) applies to the data made available in this article, unless otherwise stated in a credit line to the data. 
against potentially pathogenic bacteria by competing for nutrients or interfering with adhesion to epithelial cell receptors [1]. That's why it is believed that genitourinary disorders are often associated with changes in vaginal microflora $[11,12]$. On the other hand it has been shown that bacterial species isolated from bitches with reproductive disorders do not differ significantly from those found in healthy bitches [10]. Kustritz suggested that reproductive tract infections are caused by overgrowth of normal local microbial flora, so it may be important for the outcomes of bacteriologic tests to be quantitative [9].

\section{The aim}

Limited information is available about qualitative and quantitative composition of the natural vaginal microflora of healthy bitches and those with infections, and moreover, the results obtained by different authors are contradictory and therefore not conclusive. The aim of this study was to determine bacterial populations in various stages of the estrous cycle in the vagina of healthy dogs compared with the dogs with genital tract infections. This research will contribute to the understanding of possible oral supplementation of female dogs with non-pathogenic bacteria that colonize the normal vaginal flora of healthy female dogs.

\section{Results}

A total of 39 dogs were included in this study. Ten were qualified to the 1st group with genital tract infections and 29 to the 2nd group without such infections (Table 1).

The lowest $\mathrm{pH}(5-5.5)$ values were observed in proestrus phase in individual studies in both groups. The average $\mathrm{pH}$ values were almost the same in the healthy and infected dogs, as well as between the cycle stages.

The most common bacterial isolates obtained from the vaginal tract of all dogs were Escherichia coli (16/ 39), Staphylococcus pseudintermedius (15/39) and Streptococcus canis (13/39). The prevalence of Gramnegative rods (other than $E$. coli) was significantly higher $(p<0,05)$ generally in the group with genital tract infection (5/10) versus healthy dogs (4/29) (Fig. 1). E. coli was isolated from the vaginal tract of $50 \%$ dogs from the 1 st group and of $41.4 \%$ dogs from the 2 nd group. Staphylococcus pseudintermedius was isolated from 30\% dogs in the 1st group and of $37.9 \%$ dogs from 2nd group and Streptococcus canis from 20 and $37.9 \%$, respectively.

During the anestrus phase, E. coli was found in 5 out of $8(62.5 \%)$ dogs with genital tract infections and in 5 of $16(31.2 \%)$ of healthy dogs, and Gram-negative rods in 4 out of $8(50 \%)$ and 2 out of 16 (12.5\%), respectively. $S$. intermedius was isolated of 3 out of 8 (37.5\%) dogs from the 1st group and from 9 of $16(56.2 \%)$ in the 2nd group and $S$. canis in 1 out of 8 (12.5\%) and 4 of 16 (25\%), respectively. Enterococcus spp. in this phase was found in 2 out of $8(25 \%)$ in the 1 st group and 3 out of $16(18.7 \%)$ in the 2nd group (Fig. 2).

During the proestrus phase, E.coli was not found in the 1st group and was isolated from 3 of 9 (33.3\%) in the 2nd group and Gram-negative rods in 1 out of 2 (50\%) and 2 out of 9 (22.2\%), respectively (Fig. 2). S. pseudintermedius was found in 1 out of 3 (33\%) dogs with genital tract infections and in 1 out of 9 (11.1\%) healthy dogs. S. canis was not found in the vagina of dogs from the 1st group but it was isolated from 5 of 9 (55.5\%) dogs in the 2nd group. Enterococcus spp. in this phase was found in 1 out of $2(50 \%)$ in the 1st group and 1 out of $9(11 \%)$ in the 2 nd group.

The total number of bacteria was almost the same in the healthy and infected dogs, as well as between the cycle stages.

Mycoplasma spp. was found in all dogs from the 1st group. In the group of healthy dogs Mycoplasma spp. was found in 18 of 39 (62\%) dogs (9/16 in anestrus, 7/9 in proestrus, 2/4 in diestrus) and Mycoplasma canis in 2 (22.2\%) animals in proestrus and 1 (25\%) in diestrus phase. There was no presence of Chlamydiaceae or Chlamydia abortus in tested swabs.

There was no presence of lactic acid-producing bacteria in the tested materials.

Based on statistical analysis, we revealed significant differences $(p<0.05)$ in the occurrence of S. pseudintermedius in the group of healthy dogs between the anestrus and proestrus phase.

There were no significant differences in the quantity of bacteria in any of the cycle stages and between healthy and infected groups.

\section{Discussion}

This study was aimed to determine bacterial populations in various stages of the estrous cycle in the vagina of healthy dogs compared with the dogs with genital tract

Table 1 Clinical groups of tested animals

\begin{tabular}{|c|c|c|c|c|c|c|}
\hline \multirow{2}{*}{$\begin{array}{l}\text { Clinical } \\
\text { groups }\end{array}$} & \multicolumn{3}{|l|}{ Healthy } & \multicolumn{3}{|c|}{ With genital tract infections } \\
\hline & $N=32$ & & & $N=10$ & & \\
\hline \multirow[t]{2}{*}{ Estrous phase } & Anestrus & Proestrus/Oestrus & Diestrus & Anestrus & Proestrus & Diestrus \\
\hline & $N=16$ & $N=10$ & $N=5$ & $N=8$ & $N=2$ & $N=0$ \\
\hline
\end{tabular}




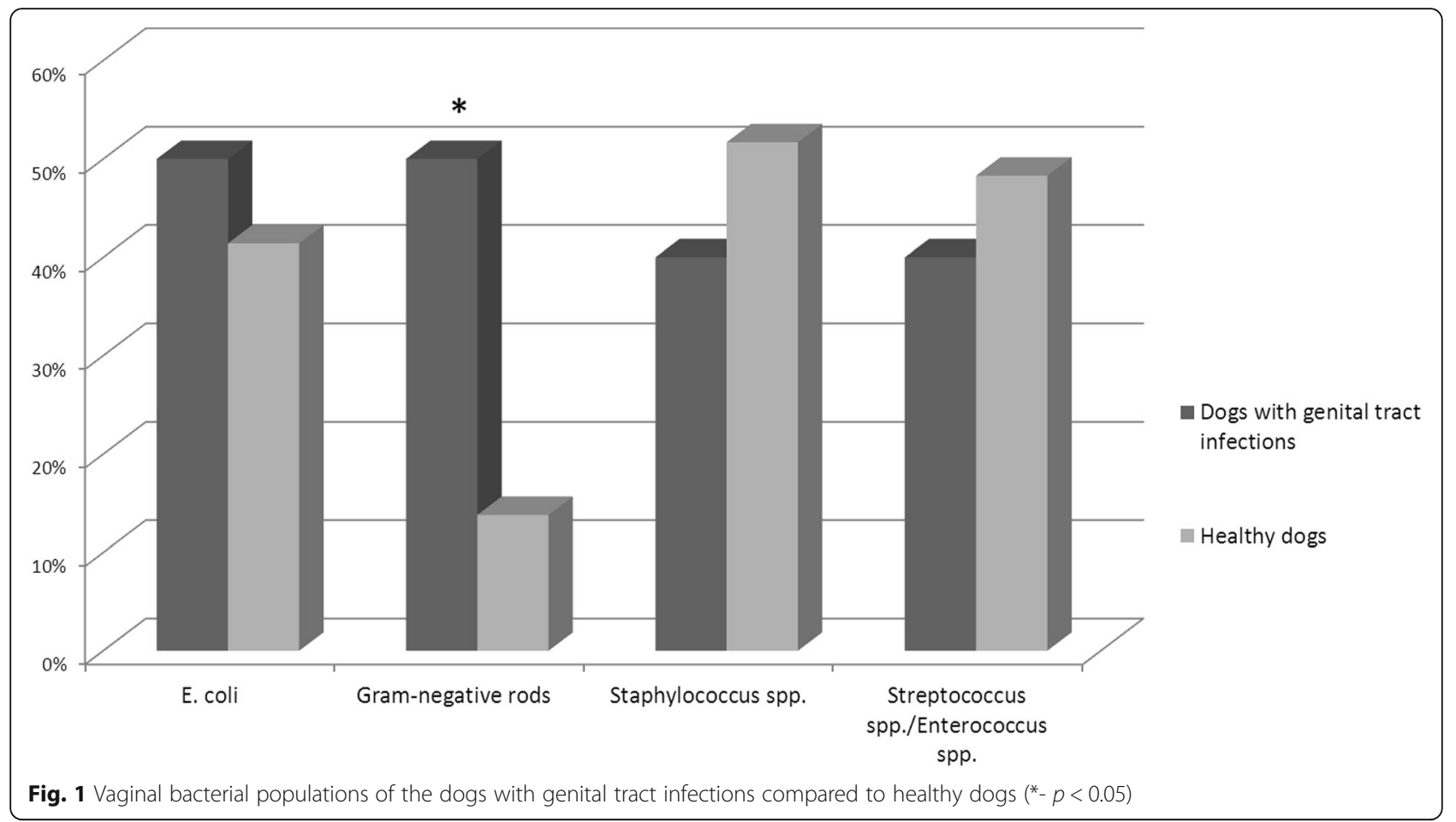

infections. The results suggest that there is a some variety in quantity and type of bacteria between different stages of the estrous cycle. The prevalence of common pathogens, such as E. coli, S. pseudintermedius, S. canis and Enterococcus spp., was similar between group of dogs with genital tract infections and the healthy ones. Almost the same results were obtained by Hutchins et al. [13]. Because bacteria are normal inhabitants of the lower reproductive tract, it is very difficult to determine if they are potentially pathologic or not, simply based on their presence. However, it is possible that a significant difference in the prevalence of specific pathogens such as $E$. coli would be identified in a larger study population. Only the presence of Gram-negative rods (other than E.coli) was significantly higher in the 1st group.

There was a large increase of E.coli and other Gramnegative rods population in anestrus phase in the vaginal swabs of dogs with infections. In contrast, S. pseudintermedius was most common in this phase in vaginal swabs

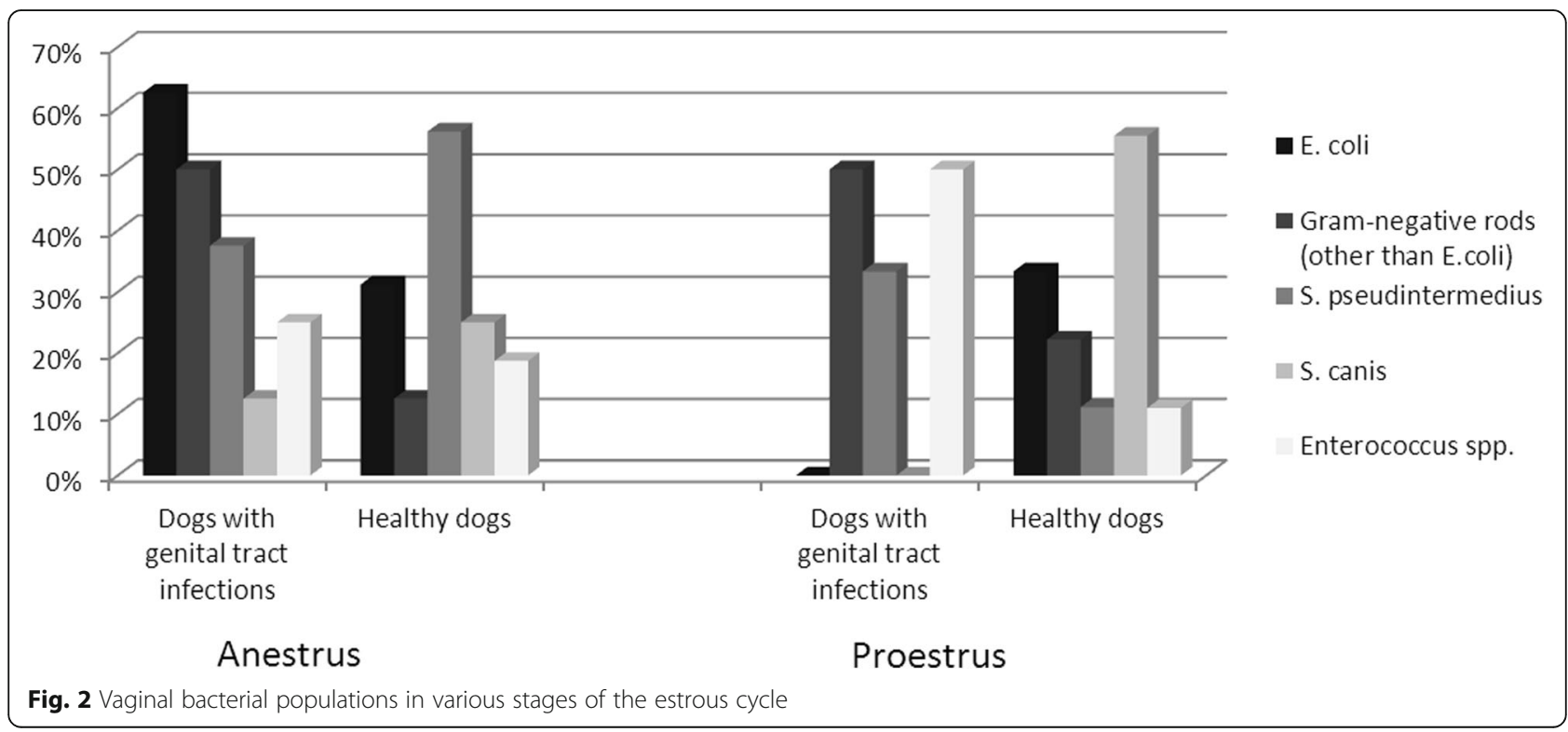


of healthy dogs. Population of Gram-negative rods was almost the same in both estrus phases in the 1st group, whereas there was a large increase of Enterococcus spp. and large decrease of $E$. coli in proestrus phase.

Streptococcus canis is much more common in proestrus phase in healthy dogs, in contrast to Enterococcus spp. whose presence was more often noticed in dogs with genital tract infections. Therefore, it can be suspected that Staphylococcus spp. and Streptococcus spp. can act as protection against more dangerous pathogens, by competing for nutrients or interfering with adhesion to epithelial cell receptors. Or it could be due to the presence of blood in the vagina during proestrus.

We, like other research groups [14-16], observed that Mycoplasma spp. are common pathogens in the genital tract of tested groups. There was no relationship between the presence of Mycoplasma and the symptoms of infections.

This study shows a complete absence of Lactobacillus species in the genital tracts of tested dogs, unlike the vaginal microbiota of woman, where lactobacilli are predominant colonizers [17]. This result is in apparent disagreement with the studies of Delucchi [11] and Hurchins [12] groups. The cause for this is not clear. One of the possible explanations is the fact that in this study we used a sterile vaginal specula to collect swab samples, whereas in the previous studies an unguarded swab was used. This could cause contamination of the sample from the vestibule or vulva. However, Lyman et al. [16] using DNA sequencing observed that lactobacilli in the canine vagina represent only $0.03 \%$ of all bacterial populations. The same was observed in cow and ewe reproductive tracts [18].

In our study, the vaginal $\mathrm{pH}$ in dogs ranged from 5.0 to 8.1. This could be connected with the absence of lactic acid bacteria. In humans, where lactobacilli are predominant members of the microbiota, the normal vaginal $\mathrm{pH}$ is 4.5 or even lower.

Our own results, as well as results of other authors [7], pay particular attention to the important aspect of collecting knowledge in the field of vaginal microbiota as the starting point to find a way to effectively prevent urogenital infections.

\section{Conclusion}

In conclusion, cultures of the vaginal canal will almost always result in growth of bacteria and interpretation of this growth is very difficult in terms of determining the need for treatment. In fact, bacterial culturing of vaginal swab specimens from bitches without signs of genital disease is of little value. It should always be preceded by clinical examination and cytological examination of the vaginal epithelium.

\section{Methods}

\section{Samples collection}

Client-owned dogs were carried to the Veterinary Clinic of the University Center of Veterinary Medicine JU-AU, University of Agriculture in Cracow, Poland in connection with reproductive problems, estrous monitoring, determination of mating date or routine gynaecological examination of breeding bitches. The owners were informed about the purpose of the study and gave their written consent for their dogs to participate in the study.

Samples for microbiology were collected from 39 bitches of different breeds, aged from 6 months to 10 years (mean $4.45 \pm 2.4$ ) (Table 1). The study included bitches in good shape only, showing no systemic or organ diseases (excluding the symptoms of vaginitis). Bitches undergoing any treatment were excluded. Animals were not given antibiotics for at least 2 weeks prior to collection.

Before samples' collection, the veterinarian interviewed the animal owner and physical and gynaecological examinations of the bitch were performed.

Samples for microbiological examination were taken from the upper vault of the vagina, in the dorsal section, using a sterile swab and a sterile vaginal specula for bitches, model Hannover (Eickemeyer, Tuttlingen, Germany) of $150 \mathrm{~mm}$ in length and 5, 10 or $15 \mathrm{~mm}$ diameter (size adjusted to the bitch). The microbiological samples were delivered to the laboratory in the transport medium within $4 \mathrm{~h}$ from the collection.

In order to determine the phase of the cycle, cytological smears from the upper vault of the vagina of the bitches were taken with the use of a sterile swab moistened with $0.9 \% \mathrm{NaCl}$ solution. After cytological preparation on a glass slide, the smear was fixed with Cytofix ${ }^{\circ}$ (Samko, Klembów, Poland), subsequently smears were stained with a modified Wright Giemsa stain (Hemacolor staining kit, Merck, Darmstadt, Germany). After drying, the smears were evaluated under the optical microscope Leica DM2500 (Leica, Wetzlar, Germany) at the magnification of $200 \times$ and $400 \times$. Five types of epithelial cells were identified in the evaluated smear: basal cells, small intermediate cells, large intermediate cells, superficial cells and superficial cells without nuclei according to the classification proposed by Bowen [19]. In addition neutrophils, erythrocytes, bacteria, strands of mucus and cellular detritus were recognized in the smear.

\section{Qualification criteria for clinical groups Vaginal $\mathrm{pH}$ measurement}

The $\mathrm{pH}$ measurement was performed with the use of the MColorpHast $^{\mathrm{Tx}}$ indicator strips (Merck, Darmstadt, Germany) to which the tip of the vaginal speculum was applied immediately after removing it from the vagina. 
The $\mathrm{pH}$ was evaluated $2 \mathrm{~s}$. after, according to the manufacturer's recommendations.

\section{Measurement of serum progesterone levels}

$5 \mathrm{ml}$ of venous blood was drawn from each bitch. Progesterone serum level was tested by chemiluminescence using IMMULITE $^{\bullet} 1000$ apparatus (Healthineers Siemens, Erlangen, Germany).

\section{Qualifications for clinical groups}

Qualifications for clinical groups were made based on the medical history, clinical examination, cytological examination of the vaginal epithelium and the level of progesterone in the serum. First, the females were classified into groups with or without vaginitis based on the guidelines provided by Feldman and Nelson [1]. Subsequently the phase of the estrous cycle was determined.

Bitches with mucic, milky-white, yellowish or greenish vaginal discharge and the presence of numerous neutrophils in cytological smear were classified as animals with vaginitis (ill bitches, $n=10$ ). Often in bitches with vaginitis, owners observed increased licking of the vulva by the animal and polydypsia/polyuria. Moreover, strands of mucus in cytological smears were visible. Bitches without vaginitis (healthy bitches, $n=29$ ) had physiological vaginal discharge (from blood to straw coloured) or no discharge at all. The presence of few neutrophils in the cytological smear was acceptable only at the beginning of the proestrus phase, with simultaneous blood vaginal discharge and the diestrus phase, with no vaginal discharge.

In clinical terms, the whole cycle was divided into three periods: a period of heat or follicular phase, which consists of proestrus and estrus phases, the after-heat period, also called - the luteal phase, represented by the diestrus phase and the period of hormonal mute represented by the anestrus phase. The different phases of the cycle were determined on the basis of the guidelines described by Concannon [20].

Bitches in proestrus phase showed signs of increased estrogenization of the genital tract during the clinical examination, such as swelling and increased turgor of vulva (plump texture of the vulva), vaginal discharge (bloody or sero-bloody). Information from the medical interview with the owner described an increased interest of male dogs, with lacking or weak acceptance from the bitch. In the cytological picture, numerous epithelial cells were identified, from small intermediate cells through large intermediate cells, to superficial cells, mainly nucleated. In addition, numerous erythrocytes, and in the early proestrus single neutrophils (Table 2) were seen. Serum progesterone levels in the proestrus phase were below $1 \mathrm{ng} / \mathrm{ml}$.
Bitches in estrus phase performed sexual (acceptance) reflex, such as flagging of the tail (elevation of the tail away from the vulva and swaying of the hips from side to side) in response to touching the perineal region. In addition, in the clinical examination vulva was moderately swollen and had a pasty consistency (less turgid and more soft and flaccid than in proestrus). The vaginal discharge was still present, although it was lightly to straw coloured. In the cytological picture, only superficial cells, mainly without nuclei, and clear, "water-like" background was visible. The level of progesterone was above $1 \mathrm{ng} / \mathrm{ml}$, although this was not a key eligibility criterion (Table 2).

Bitches in diestrus phase did not show the acceptance reflex, had no vulvar oedema or vaginal discharge. In cytological smear vaginal epithelial cells (of various types, mainly basal and intermediate cells) arranged in strands and isolated neutrophils were seen. The progesterone serum level was above $2 \mathrm{ng} / \mathrm{ml}$ (Table 2).

In anestrus phase, bitches, just like in diestrus phase, showed no acceptance reflex tolerance, in the clinical examination the vulva was not swollen and no discharge was recognized, but in cytological vaginal smears only a few epithelial cells, including mainly basal cells were seen. The level of progesterone was less than $1 \mathrm{ng} / \mathrm{ml}$ (Table 2).

\section{Identification of vaginal bacterial populations}

The vaginal swab was transferred from the transport medium (Amies, Deltalab, Barcelona, Spain) to $1 \mathrm{ml}$ Schaedler's broth (Becton, Dickinson and Company, Sparks, MD, USA) and agitated for $1 \mathrm{~min}$. Serial decimal dilutions in the same broth were then made, and 100- $\mu$ l aliquots were plated on standard media for cultivation: McConkey agar (Oxoid Ltd., Basingstoke, Hampshire, UK) for Enterobacteriaceae, Columbia blood agar (Oxoid) with 5\% sheep blood for streptococci, BBL Enterococcosel agar (BD, Franklin Lakes, USA) for enterococci, Rogosa Agar (Merck, Darmstadt, Germany) for lactobacilli and Saboraud Agar (Merck) for Candida spp. The dilutions were then spread over plate surface by a glass rod and plates were incubated at $35^{\circ} \mathrm{C}$ for a $24 \mathrm{~h}$ (for aerobic bacteria) or $48 \mathrm{~h}$ under microaerofilic condition (for lactobacilli). The morphology of the grown colonies were analysed under magnifying glass and several colony picks of each morphological type were subcultured on appropriate media and Gramstained. After making subcultures, all colonies representing different morphotypes were counted on the plates showing appropriate colony density. Bacterial numbers were expressed as the $\log 10$ number of colony forming unit per $1 \mathrm{ml}$ (c.f.u/ml). The subcultured colonies were further incubated and after checking for purity of the cultures, phenotypic identification was performed using 
Table 2 Characteristics of the bitches used in the study

\begin{tabular}{|c|c|c|c|c|c|c|c|c|c|}
\hline \multirow{2}{*}{+2} & \multirow{2}{*}{$\begin{array}{l}\text { Dog } \\
\text { number }\end{array}$} & \multirow[t]{2}{*}{ Age } & \multirow[t]{2}{*}{$\mathrm{pH}$} & \multirow{2}{*}{$\begin{array}{l}\text { Level of } \\
\text { progesteron } \\
\text { (P4) in ng/ } \\
\mathrm{ml}\end{array}$} & \multirow{2}{*}{$\begin{array}{l}\text { Total } \\
\text { number of } \\
\text { bacteria } \\
\text { (c.f.u/ml) }\end{array}$} & \multicolumn{4}{|c|}{ Etiological factors (PCR) } \\
\hline & & & & & & $\begin{array}{l}\text { Mycoplasma } \\
\text { spp. }\end{array}$ & $\begin{array}{l}\text { Mycoplasma } \\
\text { canis }\end{array}$ & Chlamydiaceae & $\begin{array}{l}\text { Chlamydia } \\
\text { abortus }\end{array}$ \\
\hline \multicolumn{10}{|c|}{ a) Dogs with genital tract infections } \\
\hline \multirow[t]{9}{*}{ Anestrus } & 8 & 0.5 & 6.3 & $<0,2$ & $1,3 \times 10 \wedge 5$ & + & - & - & - \\
\hline & 13 & 1 & 6.0 & $<0,2$ & $1 \times 10 \wedge 3$ & + & + & - & - \\
\hline & 21 & 4 & 6.6 & $<0,2$ & $2,2 \times 10 \wedge 4$ & + & - & - & - \\
\hline & 23 & 4 & 6.6 & 0.78 & $2 \times 10 \wedge 2$ & + & - & - & - \\
\hline & 30 & 4 & 7.2 & 0.49 & $6 \times 10 \wedge 2$ & + & - & - & - \\
\hline & 37 & 4 & 6.9 & $<0,2$ & $2 \times 10 \wedge 4$ & + & - & - & - \\
\hline & 39 & 4 & 6.6 & 0.91 & $4 \times 10 \wedge 3$ & + & - & - & - \\
\hline & 40 & 4 & 6.9 & 0.99 & $1 \times 10^{\wedge} 4$ & + & - & - & - \\
\hline & average & 3.19 & 6.64 & 0.79 & $1,0 \times 10^{\wedge} 4$ & & & & \\
\hline \multirow[t]{3}{*}{ Proestrus } & 16 & 1.5 & 5.5 & 0.91 & $1 \times 10 \wedge 5$ & + & - & - & - \\
\hline & 38 & 4 & 8.1 & 0.69 & $2,8 \times 10 \wedge 3$ & + & - & - & - \\
\hline & average & 2.75 & 6.8 & 0.8 & $3,4 \times 10^{\wedge} 4$ & & & & \\
\hline \multicolumn{10}{|c|}{ b) Healthy dogs } \\
\hline \multirow[t]{17}{*}{ Anestrus } & 1 & 4 & 7.0 & $<0,2$ & $1 \times 10 \wedge 3$ & + & - & - & - \\
\hline & 2 & 3 & 7.0 & 0.4 & $\begin{array}{l}\text { lack of } \\
\text { growth }\end{array}$ & + & - & - & - \\
\hline & 4 & 10 & 7.0 & 0.27 & $2 \times 10 \wedge 4$ & + & - & - & - \\
\hline & 9 & 3 & 6.9 & 0.67 & $\begin{array}{l}\text { lack of } \\
\text { growth }\end{array}$ & + & - & - & - \\
\hline & 11 & 6 & 6.9 & 0.42 & $2,2 \times 10 \wedge 4$ & - & - & - & - \\
\hline & 12 & 2 & 6.3 & $<0,2$ & $1 \times 10 \wedge 4$ & - & - & - & - \\
\hline & 14 & 6.5 & 6.9 & 0.22 & $3 \times 10 \wedge 4$ & - & - & - & - \\
\hline & 17 & 2 & 6.9 & $<0,2$ & $2,2 \times 10 \wedge 3$ & + & - & - & - \\
\hline & 20 & 4 & 6.6 & 0.42 & $1 \times 10 \wedge 3$ & + & - & - & - \\
\hline & 24 & 3 & 6.6 & $<0,2$ & $1,1 \times 103$ & + & - & - & - \\
\hline & 27 & 4 & 6.9 & $<0,2$ & $1 \times 10 \wedge 5$ & + & - & - & - \\
\hline & 28 & 4 & 6.9 & 0.46 & $1 \times 10 \wedge 3$ & - & - & - & - \\
\hline & 29 & 4 & 6.9 & 0.95 & $2 \times 10 \wedge 2$ & - & - & - & - \\
\hline & 32 & 4 & 7.5 & 1.31 & $4,1 \times 10 \wedge 4$ & - & - & - & - \\
\hline & 41 & 4 & 6.6 & $<0,2$ & $1,4 \times 10 \wedge 3$ & - & - & - & - \\
\hline & 42 & 4 & 7.2 & $<0,2$ & $4,7 \times 10 \wedge 3$ & + & - & - & - \\
\hline & average & 4.22 & 6.88 & 0.57 & $8,2 \times 10^{\wedge} 3$ & & & & \\
\hline \multirow{8}{*}{$\begin{array}{l}\text { Proestrus/ } \\
\text { Oestrus }\end{array}$} & 6 & 4 & 7.2 & 0.41 & $1 \times 10 \wedge 4$ & + & - & - & - \\
\hline & 19 & 4 & 6.3 & 24.9 & $1 \times 10 \wedge 5$ & + & + & - & - \\
\hline & 22 & 4 & 6.9 & 0.57 & $2,8 \times 10 \wedge 3$ & + & - & - & - \\
\hline & 25 & 7 & 5.0 & 0.2 & $\begin{array}{l}\text { lack of } \\
\text { growth }\end{array}$ & + & - & - & - \\
\hline & 26 & 3 & 5.3 & 0.3 & $2 \times 10 \wedge 4$ & + & - & - & - \\
\hline & 31 & 4 & 7.2 & 0.24 & $6 \times 10 \wedge 2$ & - & - & - & - \\
\hline & 33 & 4 & 6.1 & 0.31 & $2 \times 10 \wedge 2$ & + & - & - & - \\
\hline & 34 & 4 & 5.5 & 25.4 & $5 \times 10 \wedge 3$ & + & + & - & - \\
\hline
\end{tabular}


Table 2 Characteristics of the bitches used in the study (Continued)

\begin{tabular}{|c|c|c|c|c|c|c|c|c|c|}
\hline & \multirow{2}{*}{$\begin{array}{l}\text { Dog } \\
\text { number }\end{array}$} & \multirow[t]{2}{*}{ Age } & \multirow[t]{2}{*}{$\mathrm{pH}$} & \multirow{2}{*}{$\begin{array}{l}\text { Level of } \\
\text { progesteron } \\
\text { (P4) in ng/ } \\
\text { ml }\end{array}$} & \multirow{2}{*}{$\begin{array}{l}\text { Total } \\
\text { number of } \\
\text { bacteria } \\
\text { (c.f.u/ml) }\end{array}$} & \multicolumn{4}{|c|}{ Etiological factors (PCR) } \\
\hline & & & & & & $\begin{array}{l}\text { Mycoplasma } \\
\text { spp. }\end{array}$ & $\begin{array}{l}\text { Mycoplasma } \\
\text { canis }\end{array}$ & Chlamydiaceae & $\begin{array}{l}\text { Chlamydia } \\
\text { abortus }\end{array}$ \\
\hline & 35 & 4 & 6.8 & 0.98 & $7 \times 10 \wedge 3$ & - & - & - & - \\
\hline & average & 4.22 & 6.26 & 5.92 & $1,1 \times 10 \wedge 4$ & & & & \\
\hline \multirow[t]{5}{*}{ Diestrus } & 3 & 10 & 6.1 & 3.65 & $2 \times 10^{\wedge} 4$ & - & - & - & - \\
\hline & 5 & 4.5 & 6.0 & 1.95 & $1,1 \times 10 \wedge 4$ & + & - & - & - \\
\hline & 10 & 4 & 6.6 & 4.63 & $2,7 \times 10 \wedge 4$ & - & - & - & - \\
\hline & 15 & 3 & 7.2 & 38.6 & $1,5 \times 10^{\wedge} 4$ & + & + & - & - \\
\hline & average & 5.38 & 6.48 & 12.21 & $6,1 \times 10^{\wedge} 4$ & & & & \\
\hline
\end{tabular}

commercial identification systems (API 20E, API50CH, APIStaph, APIStrep, API20NE (bioMerieux, l'Etoile, France).

\section{Polymerase chain reaction-based gene detection of Chlamydiaceae and mycoplasma}

The identification of the uncultivated microorganisms belonging to the Chlamydiaceae family, in particular the Chlamydophila abortus and Mycoplasma spp. including Mycoplasma canis was conducted using PCR. After plating the material taken from the upper vault of the vagina, the remaining material was used for DNA isolation using the commercial set Genomic Mini (A\&A Biotechnology, Poland). PCR was performed based on previously described methods and primers [21-24]: CHYF (5'-GCC TAC CGG CTT ACC AAC-3') and CHYR (5'- GGC GCA ATG ATT CTC GAT-3') primers were used for Chlamydiaceae family identification, GPO-3 (5- GGG AGC AAA CAG GAT TAG ATA CCC T-3') and MGSO (5' - TGC ACC ATC TGT CAC TCT GTT AAC CTC-3") for Mycoplasma species, pmp-F (5' -CTC ACC ATT GTC TCA GGT GGA-3') and pmp-R821 (5'ACC GTA ATG GGT AGG AGG GGT-3') for Chlamydophila abortus and MCF (5'- CAC CGC CCG TCA CAC CA-3') and MCR (5'-CTG TCG GGG TTA TCT CGA C-3) for Mycoplasma canis. The PCR products were visualized on $1.5 \%$ agarose gel with ethidium bromide staining.

\section{Statistical analysis}

Statistical analyses were performed to demonstrate significant differences in the $\mathrm{pH}$ value as well as the presence of each microbial species within the tested group. $\mathrm{pH}$ values were compared using one-way ANOVA and frequency of microbial species was analysed using Fisher's exact test. The significance level was set at $p<0.05$.

\section{Abbreviations}

PCR: Polymerase Chain Reaction
Acknowledgements

Not applicable.

\section{Authors' contributions}

EG (edyta.golinska@uj.edu.pl): investigation, data curation, formal analysis, writing - original draft, visualization. NS (nmikolajewska@gmail.com): formal analysis, investigation, resources, writing - original draft. ATP (a.tomusiak@uj. edu.pl): data curation, investigation. MS (marlena.szydlo@gmail.com): data curation, investigation. NW (n.witka@gmail.com): data curation, investigation. JL (j.lenarczyk90@gmail.com): data curation, investigation. MS (magdalena. strus@uj.edu.pl): conceptualization, methodology, resources, writing original draft, supervision, project administration, funding acquisition. All authors have read and approved the manuscript.

\section{Funding}

This study was supported by University Center of Veterinary Medicine JU-AU (grant no. 9000844). The funding agency did not participate in study design, data collection, analysis and interpretation or writing of the manuscript.

\section{Availability of data and materials}

The data and materials are available from the corresponding author on reasonable request.

\section{Ethics approval and consent to participate}

Ethics approval is deemed unnecessary according to Polish Act of December 21,1990 on the profession of veterinarian and chambers of veterinary medicine issued by the Minister of Agriculture and Food Economy. All activities described in the present study that involved animals were performed by a veterinarian as part of routine clinical veterinary procedures and with the written consent of the animal's owner.

\section{Consent for publication}

Not applicable.

\section{Competing interests}

The authors declare that they have no competing interests.

\section{Author details}

'Jagiellonian University Medical College, Czysta 18, 31-121 Cracow, Poland. ${ }^{2}$ University Center of Veterinary Medicine, University of Agriculture in Krakow, Cracow, Poland. ${ }^{3}$ Animal Reproduction Unit, Department of Genetics and Animal Breeding, Faculty of Veterinary Medicine and Animal Science, Poznan University of Life Sciences PULS, Poznan, Poland. ${ }^{4}$ Veterinary Clinic Biały Kieł, Białoruska 17a, 30-638 Cracow, Poland. ${ }^{5}$ Veterinary Clinic Felis, Dworcowa 32, 32-620 Brzeszcze, Poland. ${ }^{6}$ Veterinary Clinic Multivet, Feliksa Konecznego 6/ 12u, 31-216 Cracow, Poland.

Received: 15 April 2020 Accepted: 7 December 2020

Published online: 06 January 2021

References

1. Feldman EC, Nelson RW. Canine and feline endocrinology and reproduction. 3rd Ed. Saunders; 2003. 
2. Kustritz MR. Vaginitis in dogs: a simple approach to a complex condition. Vet Med. 2008;103:562-7.

3. Pretzer SD. Bacterial and protozoal causes of pregnancy loss in the bitch and queen. Theriogenology. 2008;70:320-6.

4. Smith FO. Canine pyometra. Theriogenology. 2006;66:610-2.

5. Noguchi K, Tsukumi K, Urano T. Qualitative and Quantitative Differences in Normal Vaginal Flora of Conventionally Reared Mice, Rats, Hamsters, Rabbits and Dogs. Comp Med. 2003;53(4):404-12.

6. Johnston S, Kustritz RM, Olson P. Canine and feline theriogenology. W. B: Saunders; 2001.

7. Groppetti D, Pecile A, Barbero C, Martino PA. Vaginal bacterial flora and cytology in proestrous bitches: role on fertility. Theriogenology. 2012;77(8): 1549-56.

8. Watts JR, Wright PJ, Whithear KC. Uterine, cervical and vaginal microflora of the normal bitch throughout the reproductive cycle. J Small Anim Pract. 1996;37:54-60

9. Root Kustritz MV. Collection of tissue and culture samples from the canine reproductive tract. Theriogenology. 2006;66:567-74.

10. Van Duijkeren E. Significance of the vaginal bacterial flora in the bitch: a review. Vet Rec. 1992;131:367-9.

11. Delucchi L, Fraga M, Perelmuter K, Cidade E, Zunino P. Vaginal lactic acid bacteria in healthy and ill bitches and evaluation of in vitro probiotic activity of selected isolates. Can Vet J. 2008;49(10):991-4.

12. Hutchins RG, Bailey CS, Jacob ME, Harris TL, Wood MW, Saker KE, Vaden SL. The effect of an oral probiotic containing lactobacillus, bifidobacterium, and bacillus species on the vaginal microbiota of spayed female dogs. J Vet Intern Med. 2013;27(6):1368-71.

13. Hutchins RG, Vaden SL, Jacob ME, Harris TL, Bowles KD, Wood MW, Bailey CS. Vaginal microbiota of spayed dogs with or without recurrent urinary tract infections. J Vet Intern Med. 2014;28(2):300-4.

14. Janowski T, Zduńczyk S, Jurczak A, Socha P. Incidence of mycoplasma canis in the vagina in three groups of bitches. Bull Vet Inst Pulawy. 2008;52:533-5.

15. Maksimović Z, Maksimović A, Halilbašić A, Rifatbegović M. Genital mycoplasmas of healthy bitches. J Vet Diagn Investig. 2018;30(4):651-3.

16. Lyman CC, Holyoak GR, Meinkoth K, Wieneke X, Chillemi KA, DeSilva U. Canine endometrial and vaginal microbiomes reveal distinct and complex ecosystems. PLoS One. 2019;14(1):e0210157.

17. Strus M, Kucharska A, Kukla G, Brzychczy-Włoch M, Maresz K, Heczko PB. The in vitro activity of vaginal Lactobacillus with probiotic properties against Candida. Infect Dis Obstet Gynecol. 2005 Jun;13(2):69-75.

18. Swartz JD, Lachman M, Westveer K, O'Neill T, Geary T, Kott RW, Berardinelli JG, Hatfield PG, Thomson JM, Roberts A, Yeoman CJ. Characterization of the vaginal microbiota of ewes and cows reveals a unique microbiota with low levels of lactobacilli and near-neutral pH. Front Vet Sci. 2014;1:19.

19. Bowen RA. Classification of vaginal epithelial cells; 1998. p. 1-3.

20. Concannon PW. Reproductive cycles of the domestic bitch. Anim Reprod Sci. 2011;124:200-10.

21. Condon $\mathrm{K}$, Oakey J. Detection of Chlamydiaceae DNA in veterinary specimens using a family-specific PCR. Lett Appl Microbiol. 2007;45(2):121-7.

22. Netto C, Soccol VT, Sepulveda L, Garcia GHO, Timenetsky J. Quality control of biotechnological inputs detecting mycoplasma. Braz Arch Biol Technol. 2015;58(2):239-43.

23. Berri M, Rekiki A, Boumedine KS, Rodolakis A. Simultaneous differential detection of Chlamydophila abortus, Chlamydophila pecorum and Coxiella burnetii from aborted ruminant's clinical samples using multiplex PCR. BMC Microbiol. 2009;9:130.

24. Chalker VJ, Owen WM, Paterson C, Barker E, Brooks H, Rycroft AN, Brownlie J. Mycoplasmas associated with canine infectious respiratory disease. Microbiology. 2004;150(Pt 10):3491-7.

\section{Publisher's Note}

Springer Nature remains neutral with regard to jurisdictional claims in published maps and institutional affiliations.

\section{Ready to submit your research? Choose BMC and benefit from:}

- fast, convenient online submission

- thorough peer review by experienced researchers in your field

- rapid publication on acceptance

- support for research data, including large and complex data types

- gold Open Access which fosters wider collaboration and increased citations

- maximum visibility for your research: over $100 \mathrm{M}$ website views per year

At BMC, research is always in progress.

Learn more biomedcentral.com/submissions 